\title{
Involvement of JNK-initiated p53 accumulation and phosphorylation of p53 in pseudolaric acid B induced cell death
}

\author{
Xianfeng Gong ${ }^{1,2}$, Minwei Wang ${ }^{2}$, \\ Shin-ichi Tashiro ${ }^{3}$, Satoshi Onodera ${ }^{3}$ \\ and Takashi Ikejima ${ }^{1,4}$ \\ ${ }^{1}$ China-Japan Research Institute of Medical and \\ Pharmaceutical Sciences \\ ${ }^{2}$ Department of Pharmacology \\ Shenyang Pharmaceutical University \\ Shenyang 110016, China \\ ${ }^{3}$ Department of Clinical and Biomedical Sciences \\ Showa Pharmaceutical University \\ Tokyo 194-8543, Japan \\ ${ }^{4}$ Corresponding author: Tel, 86-24-23844463; \\ Fax, 86-24-238444463; E-mail, ikejimat@vip.sina.com
}

Accepted 24 July 2006

Abbreviations: ERK, extracellular signal-regulated protein kinase; JNK, c-Jun N-terminal kinase; MAPK, mitogen-activated protein kinase; PKC, protein kinase $C$

\begin{abstract}
A terminal deoxynucleotidyl transferase-mediated dUTP nick end-labeling (TUNEL) assay was used to determine that apoptosis causes HeLa cell death induced by pseudolaric acid $\mathrm{B}$. The $\mathrm{C}$-Jun $\mathrm{N}$-terminal kinase (JNK) inhibitor SP600125 decreased p53 protein expression during exposure to pseudolaric acid B. SP600125 decreased the phosphorylation of p53 during pseudolaric acid B exposure, indicating that JNK mediates phosphorylation of p53 during the response to pseudolaric acid B. SP600125 reversed pseudolaric acid B-induced down-regulation of phosphorylated extracellular signal-regulated protein kinase (ERK), and protein kinase C (PKC) was activated by pseudolaric acid $B$, whereas staurosporine, calphostin $\mathrm{C}$, and $\mathrm{H} 7$ partly blocked this effect. These results indicate that p53 is partially regulated by JNK in pseudolaric acid B-induced HeLa cell death and that PKC participates in pseudolaric acid B-induced HeLa cell death.
\end{abstract}

Keywords: apoptosis; HeLa cells; JNK mitogen-activated protein kinases; protein kinase $\mathrm{C}$; pseudolaric acid B; tumor suppressor protein p53

\section{Introduction}

Pseudolaric acid B, a plant-derived diterpene acid isolated from Pseudolarix kaempferi Gordon (Pinaceae), has various physiological and pharmacological effects such as antifungal, antimicrobial ( $\mathrm{Li}$ et al., 1995), antifertility (Wang et al., 1982; 1988), and cytotoxic activity (Pan et al., 1990). Our previous studies showed that pseudolaric acid $B$ had cytotoxic activity against human cervical carcinoma HeLa cells (Gong et al., 2004) and human melanoma A375-S2 cells (Gong et al., 2005). However, the precise mechanism of this antitumor effect remains unclear.

Mitogen-activated protein kinases (MAPKs), such as extracellular signal-regulated kinase (ERK), the c-jun N-terminal kinase (JNK), and p38 MAPK are involved in signal transduction and regulation of cellular process including proliferation, cell growth, differentiation, and apoptosis (Brunet et al., 1999; Schaeffer et al.,1999; Johnson et al., 2002). ERK is involved in the control of cell growth and differentiation. In contrast, activation of JNK and p38 MAPK is associated with induction of apoptosis (Cross et al., 2000; Kowan et al., 2003).

p53 is a tumor suppressor gene that is mutated in more than $50 \%$ of all human tumors (Levine, 1997). Designing efficient ways to restore wild p53 is, therefore, one of the key issues in cancer research. Activated p53 may signal cells to undergo growth arrest, cell differentiation, or apoptosis. p53 has been described as 'the guardian of the genome', referring to its role in conserving stability by preventing genome mutation (Levine, 1997).

Protein kinase $C(P K C)$ is a multigene family of phospholipid-dependent serine-threonine kinases that plays a central role in signal transduction and has been implicated in a wide range of physiological and abnormal cellular functions, such as cell growth, transformation, and differentiation. The twelve members of the PKC superfamily that are known so far are divided into three groups based on their requirements for activation. The existence of this large family of PKC isotypes indicates that individual PKC isotypes likely have specific roles in signal transduction (Besson et al., 2000).

In this study, we investigated the involvement of JNK and its relationship with p53 in pseudolaric acid B-treated HeLa cells. Pseudolaric acid B strongly stimulated p53, while the JNK inhibitor SP600125 
markedly reversed this process. Up-regulation of PKC also contributed to pseudolaric acid B-induced cell apoptosis.

\section{Materials and Methods}

\section{Chemicals}

Pseudolaric acid B was purchased from the National Institute for the Control of Pharmaceutical and Biological Products (Beijing, China). RNase A, 3(4,5-dimethylthiazol-2-yl)-2,5-diphenyltetrazolium bromide (MTT), proteinase K, Hoechst 33258, staurosporine, calphostin $\mathrm{C}$, and $\mathrm{H} 7$ were purchased from Sigma Chemical (St. Louis, MO). JNK MAPK inhibitor (SP600125) was obtained from Calbiochem (San Diego, CA). A TACS ${ }^{\mathrm{TM}} 2$ TdT-DAB In Situ Apoptosis Detection Kit was a product of Trevigen (Gaitherburg, MD). A PKC activity assay kit was obtained from Promega (Madison, WI). Rabbit polyclonal antibodies against ERK, JNK, phosphorylated-ERK, phosphorylated-JNK, and phosphorylated-p53, mouse monoclonal antibody against p53, and horseradish peroxidase-conjugated secondary antibodies (goat-anti-rabbit and goat-antimouse) were purchased from Santa Cruz Biotechnology (Santa Cruz, CA).

\section{Cell culture}

HeLa, human cervical cells were obtained from
A

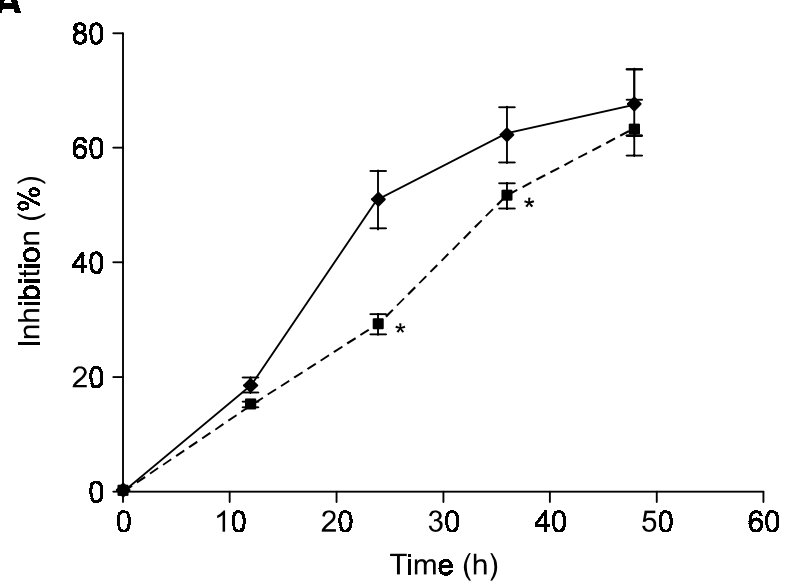

C

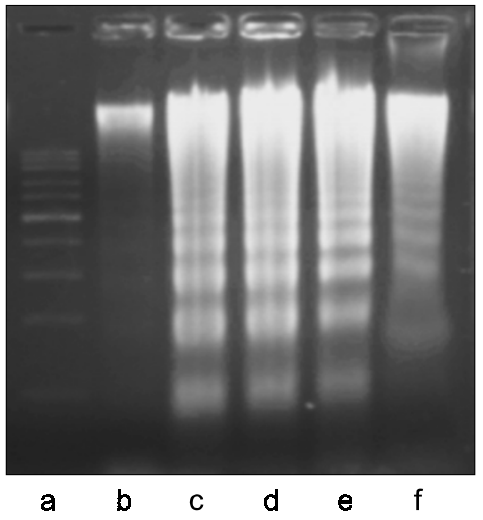

\section{B}
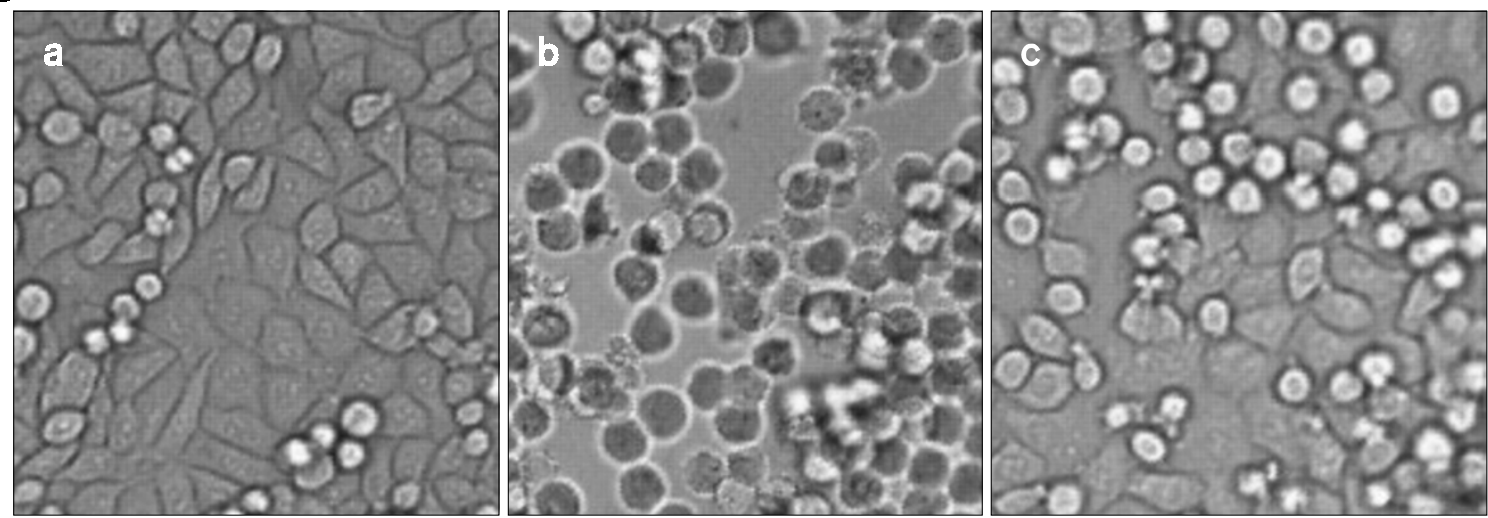

Figure 1. Effect of the JNK inhibitor SP600125 on pseudolaric acid B-induced apoptosis. One hour prior to addition of $5 \mu \mathrm{M}$ pseudolaric acid B, HeLa cells were treated with SP600125 $(20 \mu \mathrm{M})$, then further incubated for the indicated time periods. (A) Cell death was measured using an MTT assay (- --, pseudolaric acid B treated group; - --, pseudolaric acid B and SP600125 treated group). $n=3$. Mean $\pm S D * P<0.01$ vs. pseudolaric acid $B$ treated group. (B) Morphological changes were observed under phase contrast microscopy at $24 \mathrm{~h}$ (a, control; b, $5 \mu \mathrm{M}$ pseudolaric acid B-treated group; c, $5 \mu \mathrm{M}$ pseudolaric acid B and SP600125 treated group, $\times$ 200). (C) DNA fragmentation induced by pseudolaric acid $B$ and blockage of pseudolaric acid $B$ induced DNA fragmentation by SP600125 in HeLa cells. a, DNA molecular weight marker; b-e, HeLa cells were incubated with 0, 1.2, 2.5, $5 \mu \mathrm{M}$ pseudolaric acid B for $36 \mathrm{~h}$; f, HeLa cells were pretreated with $20 \mu \mathrm{M}$ SP600125 for $1 \mathrm{~h}$, then incubated with $5 \mu \mathrm{M}$ pseudolaric acid B. 
American Type Culture Collection (Manassas, VA) and cultured in RPMI-1640 medium (Hyclone, Logan, UT) supplemented with $10 \%$ heat- inactivated $\left(56^{\circ} \mathrm{C}, 30 \mathrm{~min}\right)$ fetal calf serum (Beijing Yuanheng Shengma Research Institution of Biotechnology, Beijing, China) and $2 \mathrm{mM}$ glutamine (Gibco, Grand Island, NY). Cultures were maintained at $37^{\circ} \mathrm{C}$ under a $5 \% \mathrm{CO}_{2}$ humidified atmosphere.

\section{Assessment of apoptosis}

Apoptotic cells were assessed by terminal deoxynucleotidyltransferase-mediated dUTP end labeling (TUNEL) and DNA fragmentation.

\section{Cell growth inhibition test}

The cytotoxicity of pseudolaric acid B in HeLa cells was analyzed using an MTT test. In brief, after addition of MTT $(0.5 \mathrm{mg} / \mathrm{ml})$, cells $\left(5 \times 10^{4}\right.$ cells/ well) were incubated at $37^{\circ} \mathrm{C}$ for $4 \mathrm{~h}$. DMSO $(150 \mu \mathrm{l})$ was added to dissolve formazan crystals. The absor- bance was measured at $492 \mathrm{~nm}$ using an enzyme-linked immunosorbent assay plate reader (Tecan, Salzburg, Austria).

\section{Observation of morphological changes}

HeLa cells were treated with $5 \mu \mathrm{M}$ pseudolaric acid $B$ in the presence or absence of $20 \mu \mathrm{M}$ SP600125 or $40 \mathrm{nM}$ staurosporine for indicated time periods. Morphological changes were observed under phase contrast microscopy (Leica, Wetzlar, Germany).

\section{TUNEL assay}

A TUNEL assay was used for detection of DNA strand breaks. Detection was carried out according to the instructions for the TACS ${ }^{\mathrm{TM}} 2$ TdT-DAB In Situ Apoptosis Detection Kit. Briefly, the cells were rinsed once with PBS and fixed in $3.7 \%$ buffered formaldehyde at room temperature for $10 \mathrm{~min}$. The fixed sections were pretreated with $10 \% \mathrm{H}_{2} \mathrm{O}_{2}$, and end-labeling was performed using a TdT labeling
A

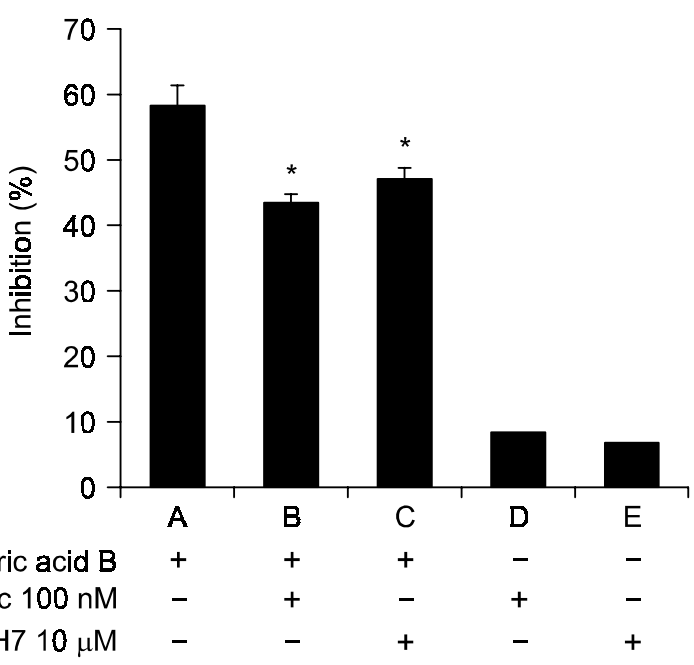

B

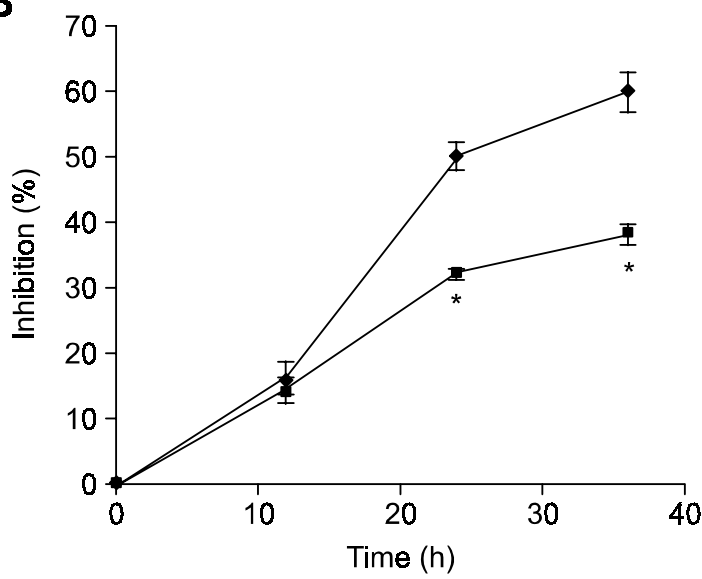

\section{C}

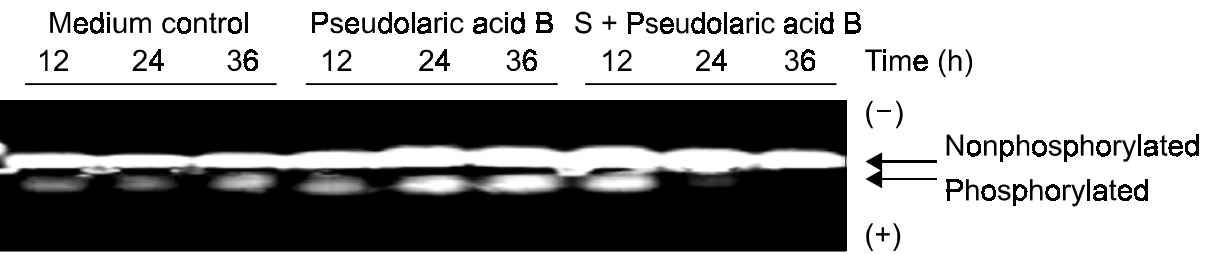

Figure 2. Effect of PKC on pseudolaric acid B-induced apoptosis. (A) One hour prior to addition of $5 \mu \mathrm{M}$ pseudolaric acid B, HeLa cells were treated with calphostin $\mathrm{C}(100 \mathrm{nM})$ or $\mathrm{H} 7(10 \mu \mathrm{M})$, then incubated for $24 \mathrm{~h}$. Cell death was measured using an MTT assay. $n=3$. Mean $\pm \mathrm{SD}{ }^{*} P<0.01$ vs. pseudolaric acid B treated group. (B) One hour prior to addition of $5 \mu \mathrm{M}$ pseudolaric acid B, HeLa cells were treated with staurosporine (40 nM), then further incubated for the indicated time periods. Cell death was measured using an MTT assay $(-\bullet-$, pseudolaric acid B treated group; - -- , pseudolaric acid B and staurosporine treated group). $n=3$. Mean $\pm S D{ }^{*} P<0.01$ vs. pseudolaric acid B treated group. (C) Effects of pseudolaric acid B on PKC activity in HeLa cells. The cells were pretreated with $40 \mathrm{nM}$ staurosporine (S) for $1 \mathrm{~h}$, incubated with $5 \mu \mathrm{M}$ pseudolaric acid B for indicated time periods, then the PKC activity was measured. 
reaction mix at $37^{\circ} \mathrm{C}$ for $1 \mathrm{~h}$. Nuclei exhibiting DNA fragmentation were visualized by incubation in 3,3'-diamino benzidine (DAB) for $7 \mathrm{~min}$. Lastly, the sections were counterstained with methyl green and observed under light microscopy. The nuclei of apoptotic cells were stained dark brown, and TUNELpositive cells were determined by randomly counting 100 cells.

\section{DNA fragmentation assay}

HeLa cells were collected by centrifugation at 1,000 $\times$ $g$ for $5 \mathrm{~min}$. The cell pellet was suspended in a cell lysis buffer (10 mM Tris- $\mathrm{HCl} \mathrm{pH} 7.4,10 \mathrm{mM}$ EDTA, $\mathrm{pH} 8.0$, Triton $\mathrm{X}-1000.5 \%$ ) and kept at $4^{\circ} \mathrm{C}$ for 30 $\min$. The lysate was centrifuged at $25,000 \times g$ for 20 $\mathrm{min}$. The supernatant was incubated with $20 \mathrm{mg} / \mathrm{ml}$ of RNase $\mathrm{A}(2 \mu \mathrm{l})$ at $37^{\circ} \mathrm{C}$ for $1 \mathrm{~h}$, then incubated with $20 \mathrm{mg} / \mathrm{ml}$ of proteinase $\mathrm{K}(2 \mu \mathrm{l})$ at $37^{\circ} \mathrm{C}$ for $1 \mathrm{~h}$. The supernatant was mixed with $5 \mathrm{M} \mathrm{NaCl}(20 \mu \mathrm{l})$ and isopropanol $(120 \mu \mathrm{l})$ at $-20^{\circ} \mathrm{C}$ overnight, then centrifuged at $25,000 \times g$ for $15 \mathrm{~min}$. After drying, DNA was dissolved in TE buffer $(10 \mathrm{mM}$ Tris- $\mathrm{HCl} \mathrm{pH}$ 7.4 , and $1 \mathrm{mM}$ EDTA, $\mathrm{pH} 8.0$ ) and separated by $2 \%$ agarose gel electrophoresis at $100 \mathrm{~V}$ for $50 \mathrm{~min}$.

\section{PKC activity assay}

A PKC activity assay was carried out according to the instructions for the PepTag ${ }^{\circledR}$ Non-Radioactive Protein Kinase C Assay Kit. Briefly, the cells were washed once with cold PBS and lysed on ice in cold lysis buffer, including $20 \mathrm{mM}$ Tris- $\mathrm{HCl}, 0.5 \mathrm{mM}$ EGTA, $2 \mathrm{mM}$ EDTA, $2 \mathrm{mM}$ dithiothreitol, $1 \mathrm{mM}$ phenylmethylsulfonyl fluoride (PMSF), and $10 \mathrm{mg} / \mathrm{ml}$ of leupeptin ( $\mathrm{pH} 7.5)$. Assays were then performed at $30^{\circ} \mathrm{C}$ in a total volume of $25 \mu$ containing $5 \mu$ of PKC reaction $5 \times$ buffer, $5 \mu$ of PLSRTLSVAAK peptide, $5 \mu$ of PKC activator, $1 \mu$ of peptide protection solution, and $9 \mu$ of sample. Reactions were initiated by addition of $9 \mu$ of sample and terminated after $30 \mathrm{~min}$ by incubation of the reaction mixture at $95^{\circ} \mathrm{C}$ for $10 \mathrm{~min}$. After adding $1 \mu \mathrm{l}$ of $80 \%$ glycerol, each sample was separated by $0.8 \%$ agarose gel electrophoresis at $100 \mathrm{~V}$ for $15 \mathrm{~min}$. Phosphorylated peptide migrated toward the anode $(+)$, while nonphosphorylated peptide migrated toward the cathode (-).

\section{Western blot analysis}

HeLa cells were treated with $5 \mu \mathrm{M}$ pseudolaric acid $B$ for indicated time periods. Both adherent and floating cells were collected and frozen at $-80^{\circ} \mathrm{C}$. Western blot analysis was then performed. Briefly, the cell pellets were resuspended in a lysis buffer, including 50 mM Hepes, pH 7.4, 1\% Triton-X 100, 2 $\mathrm{mM}$ sodium orthovanada, $100 \mathrm{mM}$ sodium fluoride, 1
mM EDTA, $1 \mathrm{mM}$ EGTA, $1 \mathrm{mM}$ PMSF, $100 \mu \mathrm{g} / \mathrm{ml}$ of aprotinin, and $10 \mu \mathrm{g} / \mathrm{ml}$ of leupeptin, then lysed at $4^{\circ} \mathrm{C}$ for $1 \mathrm{~h}$. After $13,000 \times g$ centrifugation for 10 min, the protein content of the supernatant was determined using a Bio-Rad protein assay reagent (Hercules, CA). The protein lysates were separated by $12 \%$ SDS polyacrylamide gel electrophoresis and blotted onto nitrocellulose membrane. Protein expression was detected using primary polyclonal antibodies and secondary polyclonal antibodies conjugated with horseradish peroxidase.

\section{Results}

\section{Induction of apoptosis by pseudolaric acid B}

Pseudolaric acid B induced HeLa cell death in a time- and dose-dependent manner (Gong et al., 2004). To determine the characteristics of HeLa cell death, a TUNEL assay was carried out. In the control group, the ratio of TUNEL-positive cells was $9.3 \pm 2.5 \%$. In the presence of 2.5 and $5 \mu \mathrm{M}$ pseudolaric acid $\mathrm{B}$, the numbers of apoptotic cells increased to $20.7 \pm 3.8$ and $34.7 \pm 3.0 \%$ at $24 \mathrm{~h}$, respectively (Table 1 ). These results demonstrated that apoptosis was a cause of HeLa cell death induced by pseudolaric acid $B$.

\section{Inhibitory effects of SP600125 on pseudolaric acid B-induced morphologic changes and DNA frag- mentation}

Pseudolaric acid B-induced HeLa cell death was partially inhibited by the JNK inhibitor SP600125 (Figure 1A). In order to further determine the participation of JNK in cell death, the effects of the JNK inhibitor SP600125 on cell morphological changes and DNA fragmentation were examined. SP600125 inhibited pseudolaric acid B-induced HeLa cell death (Figure 1B) and DNA fragmentation (Figure 1C).

Table 1. Quantitative analysis of TUNEL-positive HeLa cells.

\begin{tabular}{cc}
\hline Pseudolaric acid B $(\mu \mathrm{M})$ & $\begin{array}{c}\text { Apoptotic cells (\%) } \\
\text { (TUNEL-positive) }\end{array}$ \\
\hline 0 & $9.3 \pm 2.5$ \\
2.5 & $20.7 \pm 3.8^{*}$ \\
5.0 & $34.7 \pm 3.0^{* *}$ \\
\hline
\end{tabular}

The cells were treated with pseudolaric acid B for $24 \mathrm{~h}$. The results are representative of three independent experiments. All data are presented as mean $\pm S D$ and analyzed for statistical significance using Student's $t$-test. $P$ values of less than 0.05 were considered to be significant $\left({ }^{*} P<0.05,{ }^{* *} P<0.01\right)$. $P$ values are compared with the 0 $\mu \mathrm{M}$ group. 


\section{Activation of PKC in pseudolaric acid B-induced cell}

Since the PKC inhibitor, staurosporine, calphostin C, and $\mathrm{H} 7$ all markedly inhibited pseudolaric acid B-induced cell death (Figure 2A and Figure 2B), the PKC activity was measured. The PKC activity was increased by treatment with $5 \mu \mathrm{M}$ pseudolaric acid B at $24 \mathrm{~h}$ and persistently activated to $36 \mathrm{~h}$. The PKC inhibitor, staurosporine inhibited PKC activity (Figure 2C).

\section{Effects of SP600125 on protein expression and phosphorylation of p53 in pseudolaric acid B-treated HeLa cells}

p53 was activated in pseudolaric acid B-treated HeLa cells. To verify whether JNK activation was required in pseudolaric acid B-induced p53 activation, HeLa cells were incubated in the presence of SP600125 for indicated time periods. p53 expression and p53 phosphorylation in response to pseudolaric acid B were partially blocked by SP600125. Pretreatment with SP600125 effectively reversed pseudolaric acid B-induced down-regulation of ERK phosphorylation from 24 to $36 \mathrm{~h}$ (Figure 3 ).

\section{Discussion}

JNK is one of the key mediators activated by exposure to cytokines and environmental stresses that regulate inflammatory responses, cell growth, proliferation, survival, and apoptosis (Ip et al., 1998; Davis et al., 2000). In this study, we demonstrated that JNK plays an important role in pseudolaric acid B-induced cell death. Inhibition of JNK by the specific JNK inhibitor SP600125 inhibited pseudolaric acid B-induced cell death, changes in cellular morphology, and DNA fragmentation induced by pseudolaric acid $\mathrm{B}$.

The prevention of cancer is profoundly dependent on the p53 tumor suppressor protein. The ability of p53 to eliminate excess, damaged, or infected cells by apoptosis is vital for the proper regulation of cell proliferation in multi-cellular organisms (Haupt et al., 2003). p53 has been referred to as the 'gatekeeper' of genomic stability because of the important role it plays in DNA damage recognition, growth arrest, and apoptosis (Brooks et al., 2003). Our results showed that after $24 \mathrm{~h}$ of exposure to pseudolaric acid $B$ the amount of the p53 protein began to increase and, simultaneously, the amount of phosphorylated-p53 also increased, indicating that the p53 protein participates in this process.

It has been reported that p53 is also a JNK substrate (Milne et al., 1995; Fuchs et al., 1998a, b). JNK plays two distinct roles in the control of p53 activity. When inactivated, this kinase binds to residues 97-116 in p53 and targets p53 for degradation by proteasome. Expression of a cons-

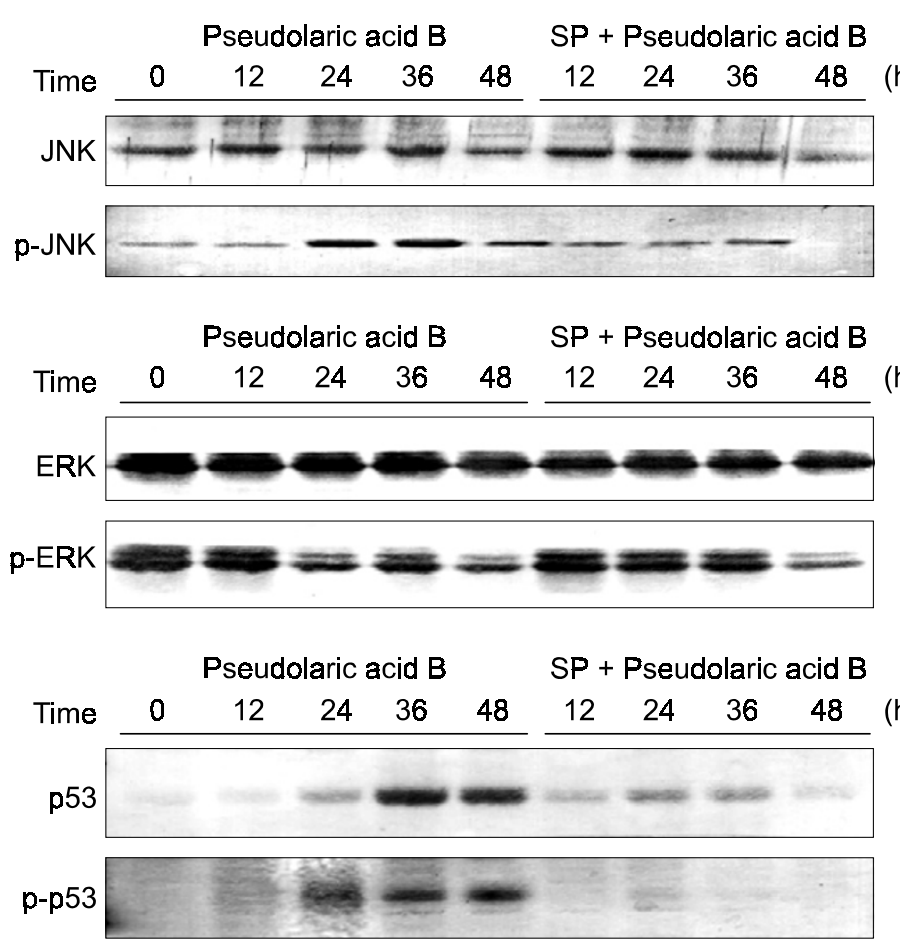

Figure 3. Effect of the JNK inhibitor SP600125 on the change of protein expression induced by pseudolaric acid-B. The cells were pretreated with $20 \mu \mathrm{M}$ SP600125 (SP) for one hour, followed by administration of $5 \mu \mathrm{M}$ pseudolaric acid $\mathrm{B}$ for the indicated time periods. Protein expression was determined by western blot analysis. 
titutively activated JNK, or activation of the upstream kinase MEKK1, increases the level of p53 by protection from degradation (Fuchs et al., 1998b). In contrast, active JNK phosphorylates p53 on threonine 81 and participates in its activation (Buschmann et al., 2001). In this study, the JNK specific inhibitor SP600125 reversed pseudolaric acid Binduced p53 activation. Pseudolaric acid B-induced phosphorylated-ERK activation was also reversed. ERK exerts a protective function against apoptosis induced by growth factor deprivation, and the dynamic balance between the ERK and JNK pathways may be important in determining cell survival (Cross et al., 2000). SP600125 increased ERK phosphorylation and decreased JNK phosphorylation, which contributed to the survival of cells. Our results indicated that p53 lies downstream of JNK, and that inhibition of ERK activation was also involved in pseudolaric acid B-induced cell death.

PKC is an attractive target for modulation of apoptosis as there is mounting evidence that PKC is a multifaceted regulator of cellular sensitivity to chemotherapeutic agents. PKC has been shown to activate the ERK pathway (Schonwasser et al., 1998). Activation of a certain PKC isozyme has also been shown to regulate $\mathrm{T}$ cell activation and macrophage apoptosis through a JNK-dependent pathway (Werlen et al., 1998; Castrillo et al., 2003; Comalada et al., 2003).

In our study, staurosporine, calphostin $\mathrm{C}$, and $\mathrm{H} 7$ markedly inhibited pseudolaric acid B-induced cell death, indicating PKC participation in this process. PKC activity was increased at $24 \mathrm{~h}$ after pseudolaric acid $B$ administration and was maintained to $36 \mathrm{~h}$, demonstrating that PKC participated in pseudolaric acid B-induced cell death.

JNK-induced activation of p53 was involved in pseudolaric acid B-induced apoptosis in HeLa cells. Simultaneously, activation of PKC also contributed to pseudolaric acid B-induced apoptosis. More details remains to be elucidated.

\section{References}

Besson A, Yong VW. Involvement of $\mathrm{p} 21^{\text {Waf1/Cip1 }}$ in protein kinase C Alpha-induced cell cycle progression. Mol Cell Biol 2000;20:4580-90

Brooks CL, Gu W. Ubiquitination, phosphorylation and acetylation: the molecular basis for p53 regulation. Curr Opin Cell Biol 2003;15:164-71

Brunet A, Roux D, Lenormand P, Dowd S, Keyse S, Pouyssegur J. Nuclear translocation of p42/p44 mitogen- activated protein kinase is required for growth factor-induced gene expression and cell cycle entry. EMBO J 1999;18:664-74

Buschmann T, Potapova O, Bar-shira A, Ivanov VN, Fuchs SY,
Henderson S, Fried VA, Minamoto T, Alarcon-vargas D, Pincus MR, Gaarde WA, Holbrook, NJ, Shiloh Y, Ronai Z. Jun $\mathrm{NH} 2$-terminal kinase phosphorylation of $\mathrm{p} 53$ on Thr-81 is important for $\mathrm{p} 53$ stabilization and transcriptional activities in response to stress. Mol Cell Biol 2001;21:2743-54

Castrillo A, Traves PG, Martin-Sanz P, Parkinson S, Parker PJ, Bosca L. Potentiation of protein kinase $C \zeta$ activity by 15-deoxy- $\Delta^{12,14}$-prostaglandin $\mathrm{J}_{2}$ induced an imbalance between mitogen-activated protein kinases and NF-kB that promotes apoptosis in macrophages. Mol Cell Biol 2003;23: 1196-208

Comalada M, Xaus J, Valledor AF, Lopez-lopez C, Pennington DJ, Celada A. PKC $\varepsilon$ is involved in JNK activation that mediates LPS-induced TNF- $\alpha$, which induces apoptosis in macrophages. Am J Physiol Cell Physiol 2003;285:1235-45

Cross TG, Scheel-Toellner D, Henriquez NV, Deacon E, Salmon M, Lord JM. Serine/Threonine protein kinases and apoptosis. Exp Cell Res 2000;256:34-41

Davis RJ. Signal transduction by the JNK group of MAP kinases. Cell 2000;103:239-52

Fuchs SY, Adler V, Buschmann T, Yin ZM, Wu XW, Jones SN, Ronai $Z$. JNK targets p53 ubiquitination and degradation in nonstressed cells. Gene Dev 1998a;12:2658-63

Fuchs SY, Adler V, Pincus MR, Ronai Z. MEKK1/JNK signaling stabilizes and activates p53. Proc Natl Acad Sci 1998b;95: 10541-6

Gong XF, Wang MW, Tashiro SI, Onodera S, Ikejima T. Pseudolaric acid B induces apoptosis through p53 and Bax/Bcl-2 pathways in human melanoma A375-S2 cells. Arch Pharm Res 2005;28:68-72

Gong XF, Wang MW, Wu Z, Tashiro SI, Onodera S, Ikejima T. Pseudolaric acid B induces apoptosis via activation of c-Jun $\mathrm{N}$-terminal kinase and caspase-3 in HeLa cells. Exp Mol Med 2004;36:551-6

Haupt S, Berger M, Goldberg Z, Haupt Y. Apoptosis-the p53 network. J Cell Sci 2003;116:4077-85

Ip YT, Davis RJ. Signal transduction by the c-Jun N-terminal kinase (JNK)-from inflammation to development. Curr Opin Cell Biol 1998;10:205-9.

Johnson GL, Lapadat R. Mitogen-activated protein kinase pathways mediated by ERK, JNK and p38 protein kinases. Science 2002;298:1911-2

Kowan KJ, Storey KB. Mitogen-activated protein kinase: new signaling pathways functioning in cellular responses to environmental stress. J Exp Biol 2003;206:1107-15

Levine AJ. p53, the cellular gatekeeper for growth and division. Cell 1997;88:323-31

Li E, Clark AM, Hufford CD. Antifungal evaluation of pseudolaric acid $\mathrm{B}$, a major constituent of pseudolarix kaempferi. J Nat Prod 1995;58:57-67

Milne DM, Campbell LE, Campbell DG, Meek DW. p53 is phosphorylated in vitro and in vivo by an ultraviolet radiation-induced protein kinase characteristic of the c-jun kinase, JNK1. J Biol Chem 1995;270:5511-6 
Pan DJ, Li ZL, Hu CQ, Chen K, Chang JJ, Lee KH. The cytotoxic principles of Pseudolarix Kaempferi: pseudolaric acid-A and B and related derivatives. Planta Med 1990;56:383-5

Schaeffer HJ, Weber MJ. Mitogen-activated protein kinase: specific messages from ubiquitous messengers. Mol Cell Biol 1999;19:2435-44

Schonwasser DC, Marais RM, Marshall CJ, Parker PJ. Activation of the mitogen-activated protein kinase/extracellular signal-regulated kinase pathway by conventional, novel and atypical protein kinase $\mathrm{C}$ isotype. Mol Cell Biol
1998; $18: 790-8$

Wang WC, Lu RF, Zhao SX, Gu ZP. Comparison of early pregnancy-terminating effect and toxicity between pseudolaric acids A and B. Acta Pharmacol Sin 1988;9:445-8

Wang WC, Lu RF, Zhao SX, Zhu YZ. Antifertility effect of pseudolaric acid B. Acta Pharmacol Sin 1982;3:188-92

Werlen G, Jacinto E, Xia Y, Karin M. Calcineurin preferentially synergizes with PKC- $\theta$ to activate JNK and IL-2 promoter in T lymphocytes. EMBO J 1998;17:3101-11 